\title{
The Value of Critical Thinking in Higher Education and the Labour Market: The Voice of Stakeholders
}

\author{
Valdonė Indrašienè, Violeta Jegelevičienè, Odeta Merfeldaitė, Daiva Penkauskienè, Jolanta Pivorienè, \\ Asta Railienè, Justinas Sadauskas *D and Natalija Valavičienè \\ Institute of Educational Sciences and Social Work, Faculty of Human and Social Studies, \\ Mykolas Romeris University, Ateities st. 20, LT-08303 Vilnius, Lithuania; \\ v.indrasiene@mruni.eu (V.I.); violeta.suboc@mruni.eu (V.J.); o.merfeldaite@mruni.eu (O.M.); \\ daiva.penkauskiene@mruni.eu (D.P.); jolantapiv@mruni.eu (J.P.); asta.railiene@mruni.eu (A.R.); \\ natalija.valaviciene@gmail.com (N.V.) \\ * Correspondence: justas_sad@mruni.eu
}

check for updates

Citation: Indrašienè, Valdonè, Violeta Jegelevičienè, Odeta Merfeldaitè, Daiva Penkauskienè, Jolanta Pivorienè, Asta Railienè, Justinas Sadauskas, and Natalija Valavičienè. 2021. The Value of Critical Thinking in Higher Education and the Labour Market: The Voice of Stakeholders. Social Sciences 10: 286. https://doi.org/10.3390/socsci 10080286

Academic Editors: Karen Arnold and Kathy Chau Rohn

Received: 17 June 2021

Accepted: 22 July 2021

Published: 27 July 2021

Publisher's Note: MDPI stays neutral with regard to jurisdictional claims in published maps and institutional affiliations.

Copyright: (C) 2021 by the authors. Licensee MDPI, Basel, Switzerland. This article is an open access article distributed under the terms and conditions of the Creative Commons Attribution (CC BY) license (https:/ / creativecommons.org/licenses/by/ $4.0 /)$.

\begin{abstract}
Critical thinking has been more than just a part of academic rhetoric and educational practice for some time now. In the rapidly changing world of information flow, critical thinking is often identified as the goal of higher education, and in the modern labour market, the importance of critical thinking to an organisation's success is emphasised. Critical thinking is recognised as one of the tools for the formation and development of human and social capital. Nevertheless, there is a lack of evidence about the manifestation in the labour market of the critical thinking developed at institutions of higher education. This article seeks to reveal the attitude toward the importance of critical thinking in the modern labour market and toward the responsibility for developing it from the perspective of different stakeholder groups (lecturers, students, employers and employees) (the case of Lithuania). Quantitative research methodology was chosen, using a questionnaire for data collection. It was found that in both higher education and the labour market, critical thinking is treated as a developed and dynamic competence that encompasses both cognitive skills and dispositions. All of the stakeholder groups consider inference and argumentation to be the most important critical thinking skills in the modern labour market. Critical thinking dispositions such as self-confidence and fairness are the most valued. All of the stakeholder groups delegate responsibility for the development of critical thinking to the individual. In evaluating critical thinking, no divide was established between the higher education and labour market segments. The most differences in attitudes emerged in evaluating the assumption of responsibility for the development of critical thinking.
\end{abstract}

Keywords: critical thinking; labour market; higher education; stakeholders

\section{Introduction}

Critical thinking was ranked by the World Economic Forum (2020) as one of the most important skills in the labour market of tomorrow. However, this demand may not be met due to the large gap between the manifestation of these skills in practice and their declared development in the formal education system. Critical thinking is relevant at all levels of education. Its distinctiveness is emphasised not only in higher education, but also in early childhood education, general education and vocational training as a core competency for lifelong learning (Brookfield 2005, 2012; Apple 2006; Halpern 2014).

The relevance of critical thinking skills in the labour market and education systems has become evident due to public social discourse. Researchers (Pithers and Soden 2000; Burbach et al. 2004; Andrews and Higson 2008; Lauder and Mayhew 2020; Hsu 2021) have long questioned the coherence between theory and practice in the development of critical thinking. The question is raised as to whether what is written in the scientific literature 
about fostering and evaluating critical thinking is not just scientific wisdom without any real application (Facione 2013).

Critical thinking is more than just a part of academic rhetoric and educational practice. The voice of employers is increasingly being heard, calling for attention to be paid to the importance of critical thinking skills in the labour market, as well as in the rapidly changing world of information overload and change in general. Studies show that employers have high expectations for critical thinking. According to employers, critical thinking creates preconditions for a person to constantly improve for the sake of organisational change (Felix 2016; Yuan et al. 2021), encourages constant response to the challenges of the changing environment and enables employees to look for the best solutions for themselves, their customers and the organisation (Indrašiene et al. 2019). It also enables employees to have self-confidence, as professionals, in dealing with difficult situations and raising questions in search of new, innovative solutions (Jiang et al. 2018).

This article seeks to reveal the attitude toward the importance of critical thinking in the modern labour market and toward the responsibility for developing it from the perspective of different stakeholder groups from Lithuania (lecturers, students, employers and employees) (the case of Lithuania). The choice of stakeholder groups was determined by the desire to examine the problem being analysed from the perspectives of higher education and the labour market. On the one hand, higher education institutions do not have sufficient evidence of how the critical thinking skills and dispositions that they develop are applied in practice. On the other hand, there is also a lack of evidence about the manifestation of the critical thinking skills of labour market participants in professional practice. The article seeks to answer the following problematic questions: (1) What are the views of the stakeholder groups regarding the manifestation and development of critical thinking? (2) How important are critical thinking skills and dispositions in the labour market? (3) Who is the responsibility for the development of critical thinking delegated to?

This quantitative study is part of an ongoing study designed to research the correspondence of higher education studies to the need for critical thinking expressed by the labour market.

\section{The Embeddedness of Critical Thinking in Higher Education and the Labour Market}

\subsection{What Is Critical Thinking?}

The concept of critical thinking, like many other concepts, is used ambiguously, giving it various meanings (Candy 1991; Kincheloe and Steinberg 1993; Penkauskienè et al. 2019; Sigurðsson 2017). Critical thinking tends to be equated with good or desirable thinking (Johnson and Hamby 2015; Pithers and Soden 2000); honest, fair behaviour (Maloney et al. 2013); the overcoming of problems (Rodzalana and Saat 2015); effective solutions (Ünsar and Engin 2013) and management of critical or crisis situations (Schraagen and van de Ven 2008). Critical thinking is directly linked to existential thinking (Saha and Ahuja 2017), higher-order thinking (Helsdingen et al. 2011; Resnick and National Research Council 1987) and liberating thinking (Apple 1995; McLaren 2016). Modern authors refer to critical thinking as an 'innovative ability', 'innovative spirit' (Zhang 2020) and a 'highly valued skill' (Aliakbari and Sadeghdaghighi 2013). The wide interpretation of the concept is conditioned by its complexity, various scientific approaches and traditions. The complexity of the concept means that it is made up of many different components. Dispositions (Dunne 2015; Facione et al. 1997; Barnett 2005; Dall'Alba and Barnacle 2007; Pollard 2014), abilities, skills and competences (Paul and Elder 2012; Ennis 2015) are all attributed to critical thinking. Thus, critical thinking as a whole is described as the totality of cognitive skills and dispositions.

\subsection{The Relevance of Critical Thinking in Higher Education}

At the academic level, there is a consensus that the development of critical thinking should be an integral part of formal education. Critical thinking is seen as a higher 
education goal or ideal that the efforts of the academic community must be directed toward (European Commission 2016; Asia Society and OECD 2018). Critical thinking is also associated with critically thinking professionals who are able to build a life and successfully collaborate with others in solving problems, making risky decisions and contributing to the well-being of society (Hsu 2021). Critical thinking skills are considered not only to be competitive (European Commission 2020), but also ones that contribute to the development of a mature, thinking, independent, proactive, creative person who is able to adapt to a wide range of social, economic, political and other circumstances (Kumar and James 2015; Halpern 2014; Christensen et al. 2021). Higher education studies are seen as an institutionalised space for the manifestation of critical thinking (Redding 2017). Its significance in higher education studies is emphasised for many reasons. Using a concept of critical thinking that emphasises higher cognitive skills as their basis, some authors (Fahim and Masouleh 2012; Bassham et al. 2013) interpreted the role of critical thinking in higher education as natural because higher education itself requires higher cognitive skills from a person. Other authors argue that critical thinking is associated with higher academic achievements because it not only helps to better understand, select and analyse information but also allows one to partake in discussions more aptly, reason logically (Stupnisky et al. 2008) and present evidence and facts, as well as generally contributing to more effective behaviour in overcoming obstacles or dealing with ordinary situations (Ghazivakili et al. 2014). Critical thinking enables students to properly select information, acting as a filter of sorts; it also encourages looking for the correct information in order to fully understand a phenomenon or process (Magrabi et al. 2018). This is important in preparing students as participants in democratic and civil societies (Barnett 2015) who will be able to expose fake news in the flow of information-in other words, deconstruct this fake 'knowledge' while also weakening the threat it poses.

It should be noted that critical thinking competences are also associated with better graduate readiness to compete in a global society (Fong et al. 2017). Critical thinking is important in the field of innovation and in the research and development activities of the universities themselves, where new products and various solutions to economic, social and environmental problems are born (Council of the European Union 2018; Halpern and Dunn 2021).

Given the intense and abundant debates on critical thinking and its development in higher education, as well as the inclusion of the term 'critical thinking' in regional and national education programming documents, it becomes clear that critical thinking is becoming increasingly important, with its role being highlighted in civic engagement, sustainable development, social justice and other civilisation processes.

\subsection{Critical Thinking in the Labour Market}

Critical thinking is named as one of the key 21st-century skills relevant to the labour market (Rave et al. 2020; Whiting 2020). In the context of a changing labour market, a new attitude toward organisations is emerging in which success is largely determined by human resources. Research shows that the success of an organisation is determined by the ability of its employees to respond quickly to changing situations and make reasoned, research-based decisions (Penkauskiené et al. 2019; Powley and Taylor 2014; AMA 2012; Phan 2011; Fung 2014). As Elicor (2017) argues, critical thinking can be an essential tool in the management of organisations, helping to find many practical solutions when operating in modern market conditions, which require a consistently high level of competitiveness and efficacy.

Today's employee needs to be able to generate new ideas without being afraid to refute old beliefs and ways of working for the sake of the organisation's success (Desai et al. 2016) and competitive advantage (Subramanian 2020). Critical thinking enables the employee to analyse and evaluate information (Sousa and Wilks 2018) and consider the situation being analysed from different perspectives (Wang and Zheng 2016; Reed 2018). According to Yanchar et al. (2008), only employees with a set of critical thinking skills 
can explain their thinking and decision-making process (Facione 2013). Critical thinking skills enable employees to analyse complex problems with a focus on the desired outcome (Power 2016); they also enable them to think creatively and independently, make decisions, draw conclusions and take action (Hassan and Madhum 2007; Piawa 2010; Abed et al. 2015; Ahrari et al. 2016; Tripathy 2020; Krstikj 2021).

Thus, in the context of the labour market, the ability to think critically helps one grasp new ideas, make difficult decisions, dynamically engage in productive and positive activities and link theoretical subjects with practical situations.

\section{Methodology}

\subsection{Participants}

A quantitative research methodology was chosen that is based on a positivist paradigm (Phillips and Burbules 2000; Creswell and Guetterman 2019). In order for the sample to be representative of the entire statistical population, a multistage probability sampling method was used by interviewing four groups of stakeholders: lecturers, students, employers and employees from all regions of the country. Representative samples were compiled on the basis of 2020 data from the (Official Statistics Portal n.d.; The State Social Insurance Fund Board SODRA n.d.).

The sample included 152 lecturers, 1512 students, 528 employers and 2012 employees.

The lecturer and student respondent groups represent the Lithuanian lecturer and student populations according to the parameters of gender, study cycle, study field group and higher education institution type (Table 1).

Table 1. Sociodemographic data for the lecturer and student groups (\%).

\begin{tabular}{ccc}
\hline & Demographic Data for the Lecturers and Students & \\
\hline & Lecturers & Students \\
\hline Women & Gender & \\
\hline Men & 64.0 & 60.3 \\
\hline & 36.0 & 39.7 \\
\hline College & Type of higher education institution & \\
\hline University & 56.6 & 28.2 \\
\hline & 63.2 & 71.8 \\
\hline Bachelor's & Cycle of study & 80.8 \\
\hline Master's & 84.9 & 17.3 \\
\hline Doctoral & 45.4 & 0.9 \\
\hline
\end{tabular}

The employer and employee respondent groups reflect the Lithuanian labour market according to the parameters of management/work experience, type of organisation, sector of professional activity and organisation size and location (Table 2). 
Table 2. Sociodemographic data for the employer and employee groups (\%).

\begin{tabular}{ccc}
\hline \multicolumn{3}{c}{ Demographic Data for the Employer and Employers } \\
\hline & Employers & Employees \\
\hline & Gender & \\
\hline Women & 59.1 & 59.8 \\
\hline Men & 40.9 & 40.2 \\
\hline & Age & \\
\hline$\leq 40$ years & 33.1 & 52.0 \\
\hline$\geq 41$ years & 66.9 & 48.0 \\
\hline Higher university & Education & 44.2 \\
\hline Higher non-university & 70.3 & 21.0 \\
\hline Post-secondary & 11.4 & 14.8 \\
\hline Other & 7.0 & 20.0 \\
\hline & 11.4 & \\
\hline$\leq 10$ years & Management/work experience & 37.3 \\
\hline $11-20$ years & 49.4 & 25.5 \\
\hline $21-30$ years & 30.9 & 20.8 \\
\hline $31-40$ years & 13.3 & 14.2 \\
\hline $41-50$ years & 5.5 & 2.1 \\
\hline
\end{tabular}

\subsection{Data Collection}

In the survey, data were collected through a questionnaire. The construction of the questionnaire was based on an analysis of scientific sources, which made it possible to distinguish critical thinking skills and dispositions. The data collection method chosen allows for comparison of the opinions of lecturers and students and of employers and employees, which, in turn, helps to reveal the similarities and differences of attitudes between the study groups. All four groups were presented with identical blocks of questions: views regarding the manifestation and development of critical thinking, the importance of critical thinking skills and dispositions in the labour market and responsibility for the development of critical thinking. In addition, a separate block of sociodemographic questions was constructed for each study group.

For validation of the prepared research instrument-i.e., the questionnaire $-n=80$ respondents were selected, i.e., 20 respondents from each target group of lecturers and students, employers and employees.

Cronbach's alpha $(\alpha)$ measure of internal consistency was used to validate the instrument and ranged from 0.961 to 0.690 .

\subsection{Research Data Analysis Methods}

IBM $^{\circledR}$ SPSS $^{\circledR}$ (Statistical Package for the Social Sciences, New York, NY, USA) 23.0 statistical software was chosen for processing the research data. Descriptive (where the arithmetic mean (M) is calculated) and inferential statistical methods were used.

Because it was established that the data distribution was not normal, nonparametric methods of statistical inference were used. Analysis of variance was used to evaluate the statistical significance of Kruskal-Wallis H differences between groups. The Kruskal-Wallis $\mathrm{H}$ test is designed to compare the positions of three or more independent samples and rank variable distributions. Post hoc Dunn's tests (Salkind 2010) were performed after the Kruskal-Wallis $\mathrm{H}$ test and recorded statistically significant differences between the groups. 


\subsection{Research Ethics}

The quantitative research was conducted according to the basic ethical rules of anonymity, voluntary participation and no harm to the participants (Panter and Sterba 2011; Jones 2015; Creswell and Creswell 2021). When conducting the survey remotely, additional measures were taken to ensure the anonymity of the respondents. When collecting data, measures were in place to ensure that the IP network identifiers (IP addresses) of the digital devices used to complete the questionnaires would not be captured and stored.

\section{Results}

\subsection{Views Regarding the Manifestation and Development of Critical Thinking}

In analysing the opinions of the different groups of respondents about the manifestation and development of critical thinking, it was found that the majority of respondents in each group agreed with the following statements: 'critical thinking can be developed'; 'there are various ways to demonstrate critical thinking'; and 'critical thinking is possible in every situation' (Table 3).

Table 3. Comparison of views regarding the manifestation and development of critical thinking (arithmetic mean (M), where 1 is 'strongly disagree' and 7 is 'strongly agree').

\begin{tabular}{ccccc}
\hline Response & Lecturers & Students & Employers & Employees \\
\hline Critical thinking can be developed & 4.35 & 4.01 & 4.15 & 3.94 \\
\hline A person can think critically if he or she wants and tries to & 3.93 & 3.87 & 3.84 & 3.76 \\
\hline A person's ability to think critically is unchanging & 2.18 & 3.00 & 2.36 & 2.96 \\
\hline Critical thinking only occurs when criticising & 1.72 & 2.93 & 3.04 & 3.93 \\
\hline There are various ways to demonstrate critical thinking & 4.18 & 3.88 & 3.83 \\
\hline Critical thinking is possible in every situation & 4.10 & 3.85 & 4.02 & 3.81 \\
\hline
\end{tabular}

There was a statistically significant difference between all four groups participating in the study regarding the view that 'critical thinking can be developed' $(\mathrm{H}=72.910$, $p<0.0001$ ) (Table 4).

The view that 'critical thinking can be developed' was most strongly supported by the lecturers and the employers. Upon comparing the responses of the employee and student groups with the responses of the lecturer and employer groups, it was found that the employees and students are less likely to agree with the statement that 'critical thinking can be developed'.

Compared to the lecturers and students, the employees were the least likely to agree with the statement that 'a person can think critically if he or she wants and tries to' $(\mathrm{H}=19.213, p<0.0001)$.

The students and the employees were much more likely than the employers and the lecturers were to support the statement that 'a person's ability to think critically is unchanging' ( $\mathrm{H}=208.708, p<0.0001)$. Meanwhile, the lecturers were the least likely to support this statement among all of the study groups.

The statement that 'critical thinking only occurs when criticising' $(\mathrm{H}=295.502$, $p<0.0001$ ) was evaluated similarly by the employees and the students as well as the employers and the lecturers. The students and the employees were more likely than the employers and the lecturers were to support this statement.

Out of all four groups, the lecturers were the most likely to agree with the statement that 'there are various ways to demonstrate critical thinking' $(\mathrm{H}=35.124, p<0.000)$. This statement was more supported by the employers than by the employees.

Compared to the employers and the lecturers, the statement that 'critical thinking is possible in every situation' $(\mathrm{H}=45.319, p<0.0001)$ was most supported by the students and least supported by the employees. 
Table 4. Comparison of the views of the different study groups regarding the manifestation and development of critical thinking.

\begin{tabular}{|c|c|c|c|c|c|c|c|c|c|c|}
\hline \multirow[b]{2}{*}{ Response } & \multicolumn{4}{|c|}{ Group (Mean Rank) Kruskal-Wallis } & \multicolumn{6}{|c|}{ Relationships between the Groups ( $p$-Value) } \\
\hline & Lecturers & Employers & Employees & Students & $\begin{array}{c}\text { Students- } \\
\text { Employees }\end{array}$ & $\begin{array}{l}\text { Students- } \\
\text { Lecturers }\end{array}$ & $\begin{array}{l}\text { Students- } \\
\text { Employers }\end{array}$ & $\begin{array}{l}\text { Employees- } \\
\text { Lecturers }\end{array}$ & $\begin{array}{l}\text { Employees- } \\
\text { Employers }\end{array}$ & $\begin{array}{l}\text { Lecturers- } \\
\text { Employers }\end{array}$ \\
\hline $\begin{array}{l}\text { Critical thinking only occurs } \\
\text { when criticising } \\
\mathrm{H}=295.502 \\
p<0.0001\end{array}$ & 1191.23 & 1463.00 & 2197.97 & 2290.38 & 0.131 & 0.000 & 0.000 & 0.000 & 0.000 & 0.076 \\
\hline $\begin{array}{l}\text { A person's ability to think } \\
\text { critically is unchanging } \\
\qquad \begin{array}{c}\mathrm{H}=208.708 \\
p<0.0001\end{array}\end{array}$ & 1368.00 & 1553.29 & 2200.06 & 2238.31 & 1.000 & 0.000 & 0.000 & 0.000 & 0.000 & 0.521 \\
\hline $\begin{array}{c}\text { Critical thinking can be } \\
\text { developed } \\
\mathrm{H}=72.910 \\
p<0.0001\end{array}$ & 2603.66 & 2319.60 & 1992.01 & 2123.33 & 0.003 & 0.000 & 0.003 & 0.000 & 0.000 & 0.030 \\
\hline $\begin{array}{l}\text { Critical thinking is possible in } \\
\text { every situation } \\
\begin{array}{c}\mathrm{H}=45.319 \\
p<0.0001\end{array}\end{array}$ & 2452.00 & 2324.50 & 2024.00 & 2094.30 & 0.394 & 0.001 & 0.000 & 0.000 & 0.000 & 1.000 \\
\hline $\begin{array}{l}\text { There are various ways to } \\
\text { demonstrate critical thinking } \\
\qquad \begin{array}{c}\mathrm{H}=35.124 \\
p<0.0001\end{array}\end{array}$ & 2545.99 & 2186.18 & 2035.41 & 2117.97 & 0.170 & 0.000 & 1.000 & 0.000 & 0.032 & 0.000 \\
\hline $\begin{array}{l}\text { A person can think critically if he } \\
\text { or she wants and tries to } \\
\qquad \begin{array}{c}H=19.213 \\
p<0.0001\end{array}\end{array}$ & 2287.16 & 2144.40 & 2027.45 & 2169.17 & 0.001 & 1.000 & 1.000 & 0.035 & 0.198 & 1.000 \\
\hline
\end{tabular}


In terms of the manifestation and development of critical thinking, the higher education and labour market representatives were in agreement that critical thinking is something that can be developed. Although none of the respondents associated critical thinking much with improvement of the thought process by changing habitual thinking patterns, they did acknowledge that critical thinking can be developed. Both groups agreed that critical thinking is changing, can be expressed in different ways in all situations and depends on each person's desire and efforts.

It should be noted that among the representatives of both higher education and the labour market, there were still people who believe that critical thinking only occurs when criticising. This attitude was more typical of the employees and students than of the employers and lecturers.

\subsection{Attitude toward the Importance of Critical Thinking Skills in the Modern Labour Market}

In evaluating the distribution of the respondents' opinions on the importance of critical thinking skills in the labour market by study group, it was found that their opinions on this issue differed somewhat (Table 5).

Table 5. Comparison of evaluation of the importance of critical thinking skills in the modern labour market (arithmetic mean (M), where 1 is 'not important at all' and 7 is 'very important').

\begin{tabular}{ccccc}
\hline Skill Group & Lecturers & Students & Employers & Employees \\
\hline Decision-making & 5.80 & 5.49 & 5.84 & 5.51 \\
\hline Inference & 5.89 & 5.50 & 6.02 & 5.50 \\
\hline Explanation & 5.71 & 5.43 & 5.86 & 5.46 \\
\hline Analysis & 5.77 & 5.31 & 5.79 & 5.23 \\
\hline Self-regulation & 5.63 & 5.59 & 5.91 & 5.70 \\
\hline Argumentation & 5.87 & 5.54 & 5.95 & 5.62 \\
\hline Interpretation & 5.82 & 5.30 & 5.92 & 5.30 \\
\hline Evaluation & 5.79 & 5.31 & 5.91 & 5.23 \\
\hline
\end{tabular}

The lecturers $(M=5.89)$ and the employers $(M=6.02)$ considered the most important skill in the modern labour market to be the ability to formulate conclusions, while the students $(M=5.59)$ and the employees $(M=5.70)$ considered it to be self-regulation. It should be noted that all groups of respondents considered argumentation to be equally important in the modern labour market (lecturers, $M=5.87$; students, $M=5.54$; employers, $\mathrm{M}=5.95$; employees, $\mathrm{M}=5.62$ ).

It was found that the levels of importance in the labour market of the ability to 'make decisions' $(\mathrm{H}=48.996, p<0.0001)$, 'formulate conclusions' $(\mathrm{H}=95.146, p<0.0001)$, 'analyse' $(\mathrm{H}=96.934, p<0.0001)$, 'interpret' $(\mathrm{H}=137.071, p<0.0001)$, 'evaluate' $(\mathrm{H}=140.492$, $p<0.0001)$ and 'argue' $(\mathrm{H}=61.220, p<0.0001)$ were evaluated similarly by the employees and the students as well as by the employers and the lecturers. Upon comparing the responses of the employee and student groups with the responses of the lecturer and employer groups, it was found that the employees and students view these skills as being less important in the modern labour market, while the lecturers and employers view these skills as being more important in the context of the modern labour market (Table 6).

It was found that the importance in the labour market of the ability to 'explain' $(\mathrm{H}=59.754, p<0.0001)$ was evaluated similarly by the employers and the lecturers as well as by the employees and the students. The employers valued the importance of 'explanation skills' significantly more than the employees and students did, and the lecturers were more likely than the students were to emphasise the importance of these skills in the modern labour market. 
Table 6. Comparison by group of evaluation of the importance of critical thinking skills in the modern labour market.

\begin{tabular}{|c|c|c|c|c|c|c|c|c|c|c|}
\hline \multirow[b]{2}{*}{ Skill } & \multicolumn{4}{|c|}{ Group (Mean Rank) (Kruskal-Wallis) } & \multicolumn{6}{|c|}{ Relationships between the Groups ( $p$-Value) } \\
\hline & Lecturers & Employers & Employees & Students & $\begin{array}{l}\text { Students- } \\
\text { Employees }\end{array}$ & $\begin{array}{l}\text { Students- } \\
\text { Lecturers }\end{array}$ & $\begin{array}{l}\text { Students- } \\
\text { Employers }\end{array}$ & $\begin{array}{l}\text { Employees- } \\
\text { Lecturers }\end{array}$ & $\begin{array}{l}\text { Employees- } \\
\text { Employers }\end{array}$ & $\begin{array}{l}\text { Lecturers- } \\
\text { Employers }\end{array}$ \\
\hline $\begin{array}{c}\text { Evaluation } \\
\mathrm{H}=140.492 \\
p<0.0001\end{array}$ & 2540.34 & 2621.85 & 1990.68 & 2025.92 & 1.000 & 0.000 & 0.000 & 0.000 & 0.000 & 1.000 \\
\hline $\begin{array}{l}\text { Interpretation } \\
\begin{array}{c}\mathrm{H}=137.071 \\
p<0.0001\end{array}\end{array}$ & 2539.18 & 2613.67 & 2025.00 & 1983.22 & 1.000 & 0.000 & 0.000 & 0.000 & 0.000 & 1.000 \\
\hline $\begin{array}{c}\text { Analysis } \\
\mathrm{H}=96.934 \\
p<0.0001\end{array}$ & 2528.44 & 2515.45 & 2004.22 & 2046.25 & 1.000 & 0.000 & 0.000 & 0.000 & 0.000 & 1.000 \\
\hline $\begin{array}{c}\text { Inference } \\
\mathrm{H}=95.146 \\
p<0.0001\end{array}$ & 2425.91 & 2537.66 & 2037.65 & 2004.32 & 1.000 & 0.000 & 0.000 & 0.001 & 0.000 & 1.000 \\
\hline $\begin{array}{c}\text { Argumentation } \\
\mathrm{H}=61.220 \\
p<0.0001\end{array}$ & 2369.03 & 2428.49 & 2086.03 & 1983.78 & 0.076 & 0.001 & 0.000 & 0.031 & 0.000 & 1.000 \\
\hline $\begin{array}{c}\text { Explanation } \\
\mathrm{H}=59.754 \\
p<0.0001\end{array}$ & 2300.12 & 2456.34 & 2063.12 & 2011.47 & 1.000 & 0.031 & 0.000 & 0.120 & 0.000 & 0.967 \\
\hline $\begin{array}{c}\text { Decision-making } \\
\mathrm{H}=48.996 \\
p<0.0001\end{array}$ & 2397.11 & 2398.24 & 2058.55 & 2028.09 & 1.000 & 0.002 & 0.000 & 0.005 & 0.000 & 1.000 \\
\hline $\begin{array}{c}\text { Self-regulation } \\
\begin{array}{c}\mathrm{H}=33.008 \\
p<0.0001\end{array}\end{array}$ & 2062.20 & 2341.50 & 2121.81 & 1997.39 & 0.014 & 1.000 & 0.000 & 1.000 & 0.001 & 0.070 \\
\hline
\end{tabular}


The employers valued the importance of 'self-regulation skills' $(\mathrm{H}=33.008, p<0.0001)$ in the modern labour market more than the students and the employees did. The employees emphasised the importance of 'self-regulation skills' in the modern labour market more than the students did.

The higher education and labour market representatives all specified inference and explanation skills as being key in the modern labour market.

Another similarity between the labour market and higher education representatives is related to their evaluation of self-regulation skills. The students and the employees considered self-regulation to be among the most important skills in the modern labour market, whereas the employers and the lecturers considered them to be of average importance in the modern labour market.

\subsection{Attitudes toward Critical Thinking Dispositions of Importance in the Modern Labour Market}

It was found that the lecturers $(M=5.98)$, students $(M=5.69)$ and employers $(M=6.27)$ specified 'fairness' as being the most important disposition in the modern labour market. The lecturers $(M=5.95)$, students $(M=5.80)$ and employees $(M=5.87)$ identified 'selfconfidence' as an important disposition in the modern labour market. 'Rightness' was considered to be one of the most important dispositions in the labour market by the employees $(\mathrm{M}=5.90)$ and the employers $(\mathrm{M}=6.23)$ (Table 7$)$.

Table 7. Evaluation of the importance of critical thinking dispositions in the modern labour market (arithmetic mean (M), where 1 is 'not important at all' and 7 is 'very important').

\begin{tabular}{ccccc}
\hline Disposition & Lecturers & Students & Employers & Employees \\
\hline Impartiality & 5.48 & 5.25 & 5.95 & 5.3 \\
\hline Accuracy & 5.94 & 5.64 & 6.09 & 5.71 \\
\hline Fairness & 5.98 & 5.69 & 6.27 & 5.83 \\
\hline Caring for other people & 5.34 & 5.37 & 5.9 & 5.53 \\
\hline Inquisitiveness & 5.49 & 5.29 & 5.4 & 5.22 \\
\hline Self-confidence & 5.95 & 5.8 & 6.02 & 5.87 \\
\hline Flexibility & 5.95 & 5.61 & 6.02 & 5.73 \\
\hline Attentiveness & 5.68 & 5.65 & 5.97 & 5.78 \\
\hline Endurance & 5.72 & 5.52 & 5.79 & 5.62 \\
\hline Courage & 5.6 & 5.4 & 5.71 & 5.55 \\
\hline Perseverance & 5.83 & 5.57 & 5.89 & 5.65 \\
\hline Scepticism & 4.22 & 4.72 & 4.45 & 4.47 \\
\hline Open-mindedness & 5.07 & 5.09 & 5.32 & 5.13 \\
\hline Rightness & 5.76 & 5.56 & 6.23 & 5.9 \\
\hline
\end{tabular}

Comparing all four study groups in terms of their attitude toward the importance of each of the critical thinking dispositions in the modern labour market, it was found that the employers were more likely to emphasise the importance of 'impartiality' $(\mathrm{H}=124.901$, $p<0.0001)$ and 'rightness' $(\mathrm{H}=114.368, p<0.0001)$ than the lecturers, employees and students were. The employees emphasised the importance of the disposition of 'rightness' in the modern labour market more than the students did (Table 8).

All four groups similarly evaluated the importance of the dispositions of 'accuracy' $(\mathrm{H}=68.176, p<0.0001)$, 'flexibility' $(\mathrm{H}=44.271, p<0.0001)$ and 'perseverance' $(\mathrm{H}=31.360$, $p<0.0001)$. The employers emphasised the importance of these dispositions more than the students and the employees did. The lecturers valued the importance of these dispositions in the modern labour market more than students did. 
Table 8. Comparison by group of evaluation of the importance of critical thinking dispositions in the modern labour market.

\begin{tabular}{|c|c|c|c|c|c|c|c|c|c|c|}
\hline \multirow[b]{2}{*}{ Disposition } & \multicolumn{4}{|c|}{ Group (Mean Rank) (Kruskal-Wallis) } & \multicolumn{6}{|c|}{ Relationships between the Groups ( $p$-Value) } \\
\hline & Lecturers & Employers & Employees & Students & $\begin{array}{l}\text { Students- } \\
\text { Employees }\end{array}$ & $\begin{array}{l}\text { Students- } \\
\text { Lecturers }\end{array}$ & $\begin{array}{l}\text { Students- } \\
\text { Employers }\end{array}$ & $\begin{array}{c}\text { Employees- } \\
\text { Lecturers }\end{array}$ & $\begin{array}{l}\text { Employees- } \\
\text { Employers }\end{array}$ & $\begin{array}{l}\text { Lecturers- } \\
\text { Employers }\end{array}$ \\
\hline $\begin{array}{c}\text { Impartiality } \\
\mathrm{H}=124.901 \\
p<0.0001\end{array}$ & 2167.18 & 2624.41 & 2059.61 & 1970.81 & 0.163 & 0.305 & 0.000 & 1.000 & 0.000 & 0.000 \\
\hline $\begin{array}{c}\text { Rightness } \\
\mathrm{H}=114.368 \\
p<0.0001\end{array}$ & 2059.93 & 2468.12 & 2173.54 & 1884.58 & 0.000 & 0.448 & 0.000 & 1.000 & 0.000 & 0.001 \\
\hline $\begin{array}{c}\text { Fairness } \\
\mathrm{H}=112.165 \\
p<0.0001\end{array}$ & 2250.28 & 2550.47 & 2098.32 & 1936.77 & 0.000 & 0.009 & 0.000 & 0.716 & 0.000 & 0.030 \\
\hline $\begin{array}{c}\text { Caring for others } \\
\mathrm{H}=75.542 \\
p<0.0001\end{array}$ & 1955.43 & 2455.49 & 2126.66 & 1961.87 & 0.000 & 1.000 & 0.000 & 0.499 & 0.000 & 0.000 \\
\hline $\begin{array}{c}\text { Accuracy } \\
\mathrm{H}=68.176 \\
p<0.0001\end{array}$ & 2317.94 & 2455.87 & 2076.11 & 1992.56 & 0.211 & 0.006 & 0.000 & 0.082 & 0.000 & 1.000 \\
\hline $\begin{array}{l}\text { Flexibility } \\
\mathrm{H}=44.271 \\
p<0.0001\end{array}$ & 2341.11 & 2360.78 & 2094.45 & 1999.04 & 0.097 & 0.003 & 0.000 & 0.071 & 0.000 & 1.000 \\
\hline $\begin{array}{l}\text { Scepticism } \\
\mathrm{H}=32.097 \\
p<0.0001\end{array}$ & 1820.64 & 1997.57 & 2057.53 & 2227.31 & 0.000 & 0.000 & 0.001 & 0.108 & 1.000 & 0.639 \\
\hline $\begin{array}{c}\text { Perseverance } \\
\mathrm{H}=31.360 \\
p<0.0001\end{array}$ & 2286.53 & 2319.34 & 2100.87 & 2010.45 & 0.138 & 0.033 & 0.000 & 0.353 & 0.001 & 1.000 \\
\hline $\begin{array}{c}\text { Attentiveness } \\
\mathrm{H}=28.296 \\
p<0.0001\end{array}$ & 2059.13 & 2307.90 & 2126.08 & 2003.76 & 0.012 & 1.000 & 0.000 & 1.000 & 0.009 & 0.122 \\
\hline $\begin{array}{c}\text { Courage } \\
\mathrm{H}=24.498 \\
p<0.0001\end{array}$ & 2149.31 & 2256.45 & 2140.57 & 1993.37 & 0.001 & 0.711 & 0.000 & 1.000 & 0.261 & 1.000 \\
\hline $\begin{array}{c}\text { Endurance } \\
\mathrm{H}=14.859 \\
p<0.01\end{array}$ & 2186.26 & 2248.28 & 2112.30 & 2030.14 & 0.236 & 0.704 & 0.001 & 1.000 & 0.106 & 1.000 \\
\hline $\begin{array}{c}\text { Self-confidence } \\
\mathrm{H}=14.226 \\
p<0.0001\end{array}$ & 2227.92 & 2240.78 & 2106.24 & 2036.63 & 0.464 & 0.313 & 0.003 & 1.000 & 0.105 & 1.000 \\
\hline $\begin{array}{c}\text { Inquisitiveness } \\
\mathrm{H}=9.000 \\
p>0.05\end{array}$ & 2279.29 & 2201.73 & 2067.18 & 2097.08 & 1.000 & 0.416 & 0.474 & 0.195 & 0.117 & 1.000 \\
\hline
\end{tabular}


It was found that among the groups that participated in the study, the importance of the disposition of 'fairness' in the modern labour market $(\mathrm{H}=112.165, p<0.0001)$ was most strongly emphasised by the employers. The importance of the disposition of fairness was least emphasised by the students, while the evaluations of the lecturers and the employees were similar.

The employers were more likely than the other study groups (employees, lecturers, students) were to emphasise the importance of 'caring for others' $(\mathrm{H}=75.542, p<0.0001)$ in the modern labour market. The employees emphasised the importance of this disposition more than the students did.

No statistically significant difference was found between the study groups in analysing the importance of the dispositions of 'inquisitiveness' $(\mathrm{H}=9.000, p>0.05)$ and 'openmindedness' $(\mathrm{H}=5.632, p>0.05)$ in the labour market.

The employers valued the importance of the dispositions of 'self-confidence' $(\mathrm{H}=14.226, p<0.0001)$ and 'endurance' $(\mathrm{H}=14.859, p<0.01)$ in the modern labour market more than the students did.

The employers valued the importance of the disposition of 'attentiveness' $(\mathrm{H}=28.296$, $p<0.0001)$ in the modern labour market more than the students and the employees did. The employees emphasised the importance of the disposition of 'attentiveness' in the modern labour market more than the students did.

Compared to the employers and the employees, the students valued the importance of 'courage' $(\mathrm{H}=24.498, p<0.0001)$ in the modern labour market the least.

The students emphasised the importance of the disposition of 'scepticism' $(\mathrm{H}=32.097$, $p<0.0001)$ in the modern labour market more than the other study groups did.

While evaluating the importance of critical thinking dispositions in the modern labour market, it came to light that the representatives of both higher education and the labour market considered the most important critical thinking dispositions to be 'self-confidence' and 'fairness'. The dispositions of 'open-mindedness', 'inquisitiveness' and 'scepticism' were considered by both groups to be the least important in the modern labour market.

\subsection{Attitude Regarding Who Is Responsible for Developing Critical Thinking}

All four groups of respondents were found to agree that the individual is responsible for developing his or her own critical thinking (lecturers, $M=6.32$; students, $M=6.10$; employers, $\mathrm{M}=6.18$; employees, $\mathrm{M}=6.05$ ) (Table 9).

Table 9. Delegation of responsibility for developing a person's critical thinking skills (arithmetic mean (M), where 1 is 'strongly disagree' and 7 is 'strongly agree').

\begin{tabular}{ccccc}
\hline Response & Lecturers & Students & Employers & Employees \\
\hline $\begin{array}{c}\text { The institution of higher } \\
\text { education }\end{array}$ & 5.12 & 4.85 & 5.09 & 4.78 \\
\hline $\begin{array}{c}\text { The organisation where the } \\
\text { graduate will work }\end{array}$ & 4.79 & 4.70 & 5.02 & 4.76 \\
\hline The individual him or herself & 6.32 & 6.10 & 6.18 & 6.05 \\
\hline
\end{tabular}

The statement that the higher education institution is responsible for developing a person's critical thinking $(\mathrm{H}=32.975, p<0.0001)$ was evaluated similarly by the lecturers and the employers as well as by the students and the employees. Upon comparing the responses of the employee and student groups with the responses of the lecturer and employer groups, it was found that the employees and the students tend to assign less responsibility to the higher education institution for developing a person's critical thinking skills. The lecturers and the employers were more likely to emphasise the role of the higher education institution in developing a person's critical thinking skills (Table 10). 
Table 10. Delegation of responsibility for developing a person's critical thinking skills: comparison by group.

\begin{tabular}{|c|c|c|c|c|c|c|c|c|c|c|}
\hline \multirow[b]{2}{*}{ Response } & \multicolumn{4}{|c|}{ Group (Mean Rank) (Kruskal-Wallis) } & \multicolumn{6}{|c|}{ Relationships between the Groups ( $p$-Value) } \\
\hline & Lecturers & Employers & Employees & Students & $\begin{array}{l}\text { Students- } \\
\text { Employees }\end{array}$ & $\begin{array}{l}\text { Students- } \\
\text { Lecturers }\end{array}$ & $\begin{array}{l}\text { Students- } \\
\text { Employers }\end{array}$ & $\begin{array}{c}\text { Employees- } \\
\text { Lecturers }\end{array}$ & $\begin{array}{l}\text { Employees- } \\
\text { Employers }\end{array}$ & $\begin{array}{l}\text { Lecturers- } \\
\text { Employers }\end{array}$ \\
\hline $\begin{array}{c}\text { The institution of higher } \\
\text { education } \\
\mathrm{H}=32.975 \\
p<0.0001\end{array}$ & 2373.33 & 2314.88 & 2028.00 & 2100.24 & 0.105 & 0.003 & 0.001 & 0.000 & 0.000 & 1.000 \\
\hline $\begin{array}{l}\text { The organisation where the } \\
\text { graduate will work } \\
\qquad \begin{array}{c}\mathrm{H}=23.235 \\
p<0.0001\end{array}\end{array}$ & 2081.28 & 2330.49 & 2083.69 & 2050.05 & 1.000 & 1.000 & 0.008 & 1.000 & 0.000 & 0.346 \\
\hline $\begin{array}{l}\text { The individual him or herself } \\
\qquad \begin{array}{c}H=10.154 \\
p>0.05\end{array}\end{array}$ & 2318.42 & 2140.58 & 2056.80 & 2128.31 & 0.023 & 1.000 & 0.171 & 1.000 & 1.000 & 1.000 \\
\hline
\end{tabular}


The responsibility of an organisation for developing a person's critical thinking $(\mathrm{H}=23.235, p<0.0001)$ was most emphasised by the employers. Compared to the employers, the employees and the students did not tend to overemphasise the role of the organisation in developing a person's critical thinking.

The employees were more likely than the students were to emphasise the responsibility of the individual himself or herself for the development of critical thinking skills $(\mathrm{H}=10.154$, $p<0.05)$. No statistically significant differences were found between the other evaluations of the study groups.

All of the study groups were most likely to delegate responsibility for developing critical thinking to the individual him- or herself. The responsibility of the higher education institution to develop critical thinking was emphasised more by the lecturers and the employers.

\section{Discussion}

The research findings revealed certain commonalities in the views of all four stakeholder groups regarding critical thinking. It was established that in both higher education (lecturers, students) and the labour market (employers, employees), critical thinking is treated as a competence that is developed and dynamic, and which can manifest itself in a variety of situations. Critical thinking is understood as a thought process that can be developed, and which depends on each person's desire and efforts. This suggests that in higher education and the labour market, critical thinking is considered valuable. These research findings echo the insights of scientists (Niu et al. 2013; Puig et al. 2019) that critical thinking can be developed and nurtured (Bowell and Kingsbury 2015; Bezanilla et al. 2019). It should be noted, however, that there was another opinion among the representatives of higher education and the labour market that critical thinking only occurs when criticising, and that the ability to think critically is unchanging. It can be assumed that there are still cases where critical thinking is equated with criticism in both higher education and the labour market. This attitude toward critical thinking may be due to the similarity of the term with the words 'criticism' and 'criticise', which have a negative connotation. However, critical thinking enables individuals not to criticise and negate, but rather to look for the validity of one or another opinion or phenomenon.

In evaluating the importance of critical thinking skills in the modern labour market, similarities between the evaluations of the higher education and labour market representatives emerged. All of the stakeholder groups considered inference and argumentation to be the most important critical thinking skills in the modern labour market. According to Subramanian (2020), employees need to be able to formulate convincing and appropriate conclusions by taking certain logical steps, and this allows them to avoid mistakes due to overconfidence or bias (Davitch and Folker 2017). In the context of the labour market, argumentation skills (Penkauskienè et al. 2019; Powley and Taylor 2014; AMA 2012; Kreitzberg and Kreitzberg 2011; Phan 2011; Fung 2014) are singled out as one of the most important in the decision-making process.

In the opinion of the students and the employees, self-regulation skills (self-knowledge, reflection) are considered to be among the most important critical thinking skills in the modern labour market; the employers and the lecturers, however, think that these skills are less important. The importance of self-knowledge and reflection is emphasised (Andrews 2007; Wolcott 2006; Ruutmann 2019) as a necessary precondition for the right decision. According to Rogoff (2006), reflection must become part of the daily professional activities of each member of an organisation so that what is being sought in the activities of others can be applied in personal professional activities. It can be assumed that in higher education and the labour market, critical thinking skills that enable a person to consider key issues, make decisions responsibly and act independently are important, while the ability to 'exit' one's professional/study field into a broader context is less important. In other words, the importance of critical thinking skills in the modern labour market is viewed more from the personal and interpersonal aspects, while the social aspect is left on the sideline. 
It was established that from the point of view of all of the stakeholders, not only are the mentioned skills important in the labour market, but critical thinking dispositions are as well. This is in line with the position of researchers (Mathias 2015; Healey 2012; Dwyer et al. 2017) that when assessing critical thinking, the significance of dispositions has the same weight as that of cognitive skills. It can therefore be argued that this partially refutes the opinion found in scientific literature that critical thinking is perceived more as a cognitive skill than as a disposition (Fahim and Masouleh 2012; Bassham et al. 2013). According to all of the stakeholders, critical thinking dispositions such as self-confidence and fairness are the most valued in the modern labour market. According to Facione (1990), the ideal critical thinker is usually honest in the face of personality. Self-confidence enables an organisation to create added value (King and Kitchener 2004). The dispositions of inquisitiveness, scepticism and open-mindedness are given as being the least important. Although the disposition of open-mindedness is seen by all of the stakeholders as being less important in the labour market, it is noted in scientific literature that open-mindedness allows critical thinking to be 'corrected' (Lipman 1988). Only an open-minded thinker is prepared to critically and continually evaluate his or her own attitude (Bermingham 2015). It is open-mindedness that is seen as a precondition for scepticism. There is a notable connection between open-mindedness and self-reflection, as the former promotes the result of the latter.

It should be noted that in evaluating critical thinking, no divide was established between the higher education and labour market segments. The views of the stakeholder groups vary according to their level of responsibility. More so than stakeholders whose responsibilities in the context of studies and professional activities are usually expressed on a personal level (students, employees), those who have more responsibility for the quality/effectiveness of studies or organisational activities (lecturers, employers) tend to view most critical thinking skills and dispositions as being important in the labour market.

The responsibility for developing critical thinking was delegated by all of the stakeholders to the individual and his or her desire or willingness to think critically. Thus, willingness to think critically is associated with a thought process that first and foremost depends on a person's dispositions, values and beliefs to think openly, make reasoned assumptions and evaluate or weigh the persuasiveness of arguments. Devlin (2002) and Marton et al. (1993) noted that the learner's own assumption of personal responsibility for learning is crucial in the development process. Personal responsibility is a component of metacognition, without which improvement is impossible. Although all of the stakeholder groups delegated responsibility for the development of critical thinking to the individual, the role of the higher education institution is particularly highlighted in the scientific literature. According to the provisions of the Promoting Critical Thinking in European Higher Education Institutions: towards an educational protocol (Dominguez and PayanCarreira 2019), leaving the development of critical thinking as the sole responsibility of the individual is not allowed. It must be an integral part of higher education and research and the policy of the higher education institution. The higher education institution must take responsibility for developing critical thinking.

\section{Conclusions}

The growing and changing demand for generic and professional competencies in the labour market requires higher education to constantly readapt to the current situation. Additionally, this also means reviewing and evaluating society's needs and emerging challenges, rethinking practices for the preparation of professionals and assessing the importance of the competences being developed. The need for critical thinking is obvious in the labour market.

In order to meet the requirements of the modern labour market to prepare highly qualified professionals who are critical thinkers, critical thinking must be highlighted in strategic educational documents, and all of the stakeholders must agree on what is 
considered critical thinking. Critical thinking should be positioned as a synthesis of cognitive skills and dispositions.

The development of critical thinking must be recognised as a systematic process, and all of the participants in the process-from both higher education and the labour market-must assume responsibility for its outcomes.

The research findings could be supplemented by an analysis of the subjective understanding and experience of critical thinking of all of the stakeholders in learning and professional situations. The authors have provided initial insights in this regard, but the problem needs further investigation. As the issue is becoming more and more relevant, it would be worthwhile to develop research related to the development of critical thinking in employees to respond to the needs of the labour market.

Author Contributions: All of the authors (V.I., V.J., O.M., D.P., J.P., A.R., J.S., N.V.) participated in every stage of the research and contributed equally to the article. The names of the authors are listed in alphabetic order and do not reflect their respective contributions. All authors have read and agreed to the published version of the manuscript.

Funding: This research was funded by the European Social Fund (project No. (09.3.3-LMT-K-712-010068)) under a grant agreement with the Research Council of Lithuania (LMTLT).

Institutional Review Board Statement: The study was conducted according to the guidelines of the Declaration of Helsinki, and approved by the Institutional Review Board of the Institute of Educational Sciences and Social Work at Mykolas Romeris University, Lithuania. The permission date 12/12/2019, No ESDI-12/02.

Informed Consent Statement: Informed consent was obtained from all subjects involved in the study.

Data Availability Statement: Data sharing is not applicable to this article. No new data were created or analysed in this study.

Conflicts of Interest: The authors declare that there are no conflict of interest. The funders had no role in developing the study; collecting, analysing or interpreting the data; writing the manuscript or deciding to publish the results.

\section{References}

Abed, Soheila, Amir Hosein Mohammad Davoudi, and Davoud Hoseinzadeh. 2015. The effect of synectics pattern on increasing the level of problem solving and critical thinking skills in students of alborz province. WALIA Journal 31: 110-18.

Ahrari, Seyedali, Bahaman Abu Samah, Md Salleh Hj Bin Hassan, Nor Wahiza Abdul Wahat, and Zeinab Zaremohzzabieh. 2016. Deepening Critical Thinking Skills through Civic Engagement in Malaysian Higher Education. Thinking Skills E Creativity 22: 121-28. [CrossRef]

Aliakbari, Mohammad, and Akram Sadeghdaghighi. 2013. Teachers' perception of the barriers to critical thinking. Procedia—Social and Behavioral Sciences 70: 1-5. [CrossRef]

AMA. 2012. Critical Skills Survey. Available online: https:/ / docplayer.net/23395874-Critical-skills-survey.html (accessed on 16 June 2021).

Andrews, Jane, and Helen Higson. 2008. Graduate Employability, 'Soft Skills' Versus 'Hard' Business Knowledge: A European Study. Higher Education in Europe 33: 411-22. [CrossRef]

Andrews, Richard. 2007. Argumentation, Critical Thinking and the Postgraduate Dissertation. Educational Review 59: 1-18. [CrossRef] Apple, Michael W. 1995. Education and Power. New York and London: Routledge.

Apple, Michael W. 2006. Educating the "Right" Way: Markets, Standards, God, and Inequality. New York: Routledge.

Asia Society, and OECD. 2018. Teaching for Global Competence in a Rapidly Changing World. Available online: https: / / www.oecd-ilibrary.org / docserver $/ 9789264289024$-en.pdf?expires=1623860695\&id=id\&accname=guest\&checksum=D5F315 E3A2FA9E279C1F96F9792B370F (accessed on 16 June 2021).

Barnett, Ronald. 2005. Recapturing the Universal in the University. Educational Philosophy E Theory 37: 785-97. [CrossRef]

Barnett, Ronald. 2015. A Curriculum for Critical Being. In The Palgrave Handbook of Critical Thinking in Higher Education. Edited by Martin Davies and Ronald Barnett. New York: Palgrave Macmillan, pp. 63-76.

Bassham, Gregory, William Irwin, Henry Nardone, and James M. Wallace. 2013. Critical Thinking: A Student's Introduction, 5th ed. New York: McGraw-Hill.

Bermingham, Merinda. 2015. Clearing up “Critical Thinking”: Its Four Formidable Features. Creative Education 6: 421-27. [CrossRef] 
Bezanilla, María José, Donna Fernández-Nogueira, Manuel Poblete, and Hector Galindo-Domínguez. 2019. Methodologies for Teaching-Learning Critical Thinking in Higher Education: The Teacher's View. Thinking Skills \& Creativity 33. [CrossRef]

Bowell, Tracy, and Justine Kingsbury. 2015. Virtue and Inquiry: Bridging the Transfer Gap. In The Palgrave Handbook of Critical Thinking in Higher Education. Edited by Martin Davies and Ronald Barnett. New York: Palgrave Macmillan, pp. 233-245.

Brookfield, Stephen. 2005. The Power of Critical theory: Liberating Adult Learning and Teaching. San Francisco: Jossey-Bass.

Brookfield, Stephen. 2012. Teaching for Critical Thinking. Tools and Techniques to Help Students Question Their Assumptions. San Francisco: Jossey-Bass.

Burbach, Mark E., Gina S. Matkin, and Susan M. Fritz. 2004. Teaching Critical Thinking in an Introductory Leadership Course Utilizing Active Learning Strategies: A Confirmatory Study. College Student Journal 38: 482-93.

Candy, Philip C. 1991. Self-Direction for Lifelong Learning. San Francisco: Jossey-Bass.

Christensen, Jonas, Nils Ekelund, Margareta Melin, and Pär Widén. 2021. The Beautiful Risk of Collaborative and Interdisciplinary Research. A Challenging Collaborative and Critical Approach toward Sustainable Learning Processes in Academic Profession. Sustainability 13: 4723. [CrossRef]

Council of the European Union. 2018. Council Recommendation on Key Competences for Lifelong Learning. Available online: https: / / eur-lex.europa.eu/legal-content/EN/TXT/PDF/?uri=CONSIL:ST_9009_2018_INIT\&froM=EN (accessed on 16 June 2021).

Creswell, John W., and J. David Creswell. 2021. Research Design: Qualitative, Quantitative, and Mixed Methods Approaches. Thousand Oaks: SAGE Publishing.

Creswell, John W., and Timothy C. Guetterman. 2019. Educational Research: Planning, Conducting, and Evaluating Quantitative and Qualitative Research. Boston: Pearson.

Dall'Alba, Gloria, and Robyn Barnacle. 2007. An Ontological Turn for Higher Education. Studies in Higher Education 32: 679-91. [CrossRef]

Davitch, James M., and Robert D. Folker Jr. 2017. Operationalizing Air Force Critical Thinking. Air E Space Power Journal 31: 62-68.

Desai, Mayur S., Bruce D. Berger, and Roger Higgs. 2016. Critical Thinking Skills for Business School Graduates as Demanded by Employers: A Strategic Perspective and Recommendations. The Academy of Educational Leadership Journal 20: 10-31.

Devlin, Marcia. 2002. Taking Responsibility for Learning Isn't Everything: A Case for Developing Tertiary Students' Conceptions of Learning. Teaching in Higher Education 7: 125-38. [CrossRef]

Dominguez, Caroline, and Rita Payan-Carreira, eds. 2019. Promoting Critical Thinking in European Higher Education Institutions: Towards an Educational Protocol. Vila Real: Universidade de Trás-os-Montes e Alto Douro.

Dunne, Gerry. 2015. Beyond Critical Thinking to Critical Being: Criticality in Higher Education and Life. International Journal of Educational Research 71: 86-99. [CrossRef]

Dwyer, Christopher, Michael Hogan, Owen Harney, and Caroline Kavanagh. 2017. Facilitating a Student-Educator Conceptual Model of Dispositions towards Critical Thinking through Interactive Management. Educational Technology Research E Development 65: 47-73. [CrossRef]

Elicor, Peter Paul E. 2017. Critical Thinking and Community of Inquiry within Professional Organizations in the Developing World. Journal of Human Values 23: 13-20. [CrossRef]

Ennis, Robert Hugh. 2015. Critical Thinking: A Streamlined Conception. In The Palgrave Handbook of Critical Thinking in Higher Education. Edited by Martin Davies and Ronald Barnett. New York: Palgrave Macmillan, pp. 31-47.

European Commission. 2016. Review of the 2006 Recommendation on Key Competences for Lifelong Learning. Available online: https: / / ec.europa.eu/education/initiatives/key-competences-framework-review-2017_en (accessed on 16 June 2021).

European Commission. 2020. Relevant and High-Quality Higher Education. Available online: https://ec.europa.eu/education/ policies/higher-education/relevant-and-high-quality-higher-education_en (accessed on 16 June 2021).

Facione, Peter A., Noreen C. Facione, and Carol A. F. Giancarlo. 1997. Professional Judgement and the Disposition toward Critical Thinking. Millbrae: California Academic Press.

Facione, Peter. 1990. Critical Thinking: A Statement of Expert Consensus for Purposes of Educational Assessment and Instruction. Research Findings and Recommendations. Fullerton: California State University.

Facione, Peter. 2013. Critical Thinking: What It Is and Why It Counts. Oakland: The California Academic Press.

Fahim, Mansoor, and Nima Shakouri Masouleh. 2012. Critical Thinking in Higher Education: A Pedagogical Look. Theory E Practice in Language Studies 2: 1370-75. [CrossRef]

Felix, Sara Maria Camacho. 2016. Fostering Criticality within Neoliberal Higher Education: A Critical Action Research Study with First Year Students in Kazakhstan. Available online: http:/ / search.ebscohost.com.skaitykla.mruni.eu/login.aspx?direct=true\& $\mathrm{db}=\mathrm{ddu} \& A N=1 F 5 F 606674 \mathrm{E} 8 \mathrm{CCBB} \&$ site=ehost-live (accessed on 16 June 2021).

Fong, Carlton J., Yughi Kim, Coreen W. Davis, Theresa Hoang, and Young Won Kim. 2017. A Meta-Analysis on Critical Thinking and Community College Student Achievement. Thinking Skills \& Creativity 26: 71-83. [CrossRef]

Fung, Dennis. 2014. The Influence of Ground Rules on Chinese Students' Learning of Critical Thinking in Group Work: A Cultural Perspective. Pedagogy, Culture \& Society 22: 337-68. [CrossRef]

Ghazivakili, Zohre, Roohangiz Norouzi Nia, Faride Panahi, Mehrdad Karimi, Hayede Gholsorkhi, and Zarrin Ahmadi. 2014. The Role of Critical Thinking Skills and Learning Styles of University Students in Their Academic Performance. Journal of Advances in Medical Education \& Professionalism 2: 95-102. 
Halpern, Diane F., and Dana S. Dunn. 2021. Critical Thinking: A Model of Intelligence for Solving Real-World Problems. Journal of Intelligence 9: 22. [CrossRef]

Halpern, Diane F. 2014. Thought and Knowledge: An Introduction to Critical Thinking, 5th ed. New York: Psychology Press.

Hassan, Karma El, and Ghida Madhum. 2007. Validating the Watson Glaser Critical Thinking Appraisal. Higher Education: The International Journal of Higher Education and Educational Planning 54: 361-83. [CrossRef]

Healey, Ruth L. 2012. The Power of Debate: Reflections on the Potential of Debates for Engaging Students in Critical Thinking about Controversial Geographical Topics. Journal of Geography in Higher Education 36: 239-57. [CrossRef]

Helsdingen, Anne, Tamara van Gog, and Jeroen van Merrienboer. 2011. The Effects of Practice Schedule and Critical Thinking Prompts on Learning and Transfer of a Complex Judgment Task. Journal of Educational Psychology 103: 383-98. [CrossRef]

Hsu, Yi-Chu. 2021. An Action Research in Critical Thinking Concept Designed Curriculum Based on Collaborative Learning for Engineering Ethics Course. Sustainability 13: 2621. [CrossRef]

Indrašienè, Valdonè, Violeta Jegelevičienė, Odeta Merfeldaitė, Daiva Penkauskienė, Jolanta Pivorienè, Asta Railienė, Justinas Sadauskas, and Natalija Valavičienè. 2019. What Critical Thinking and for What? Social Welfare Interdisciplinary Approach 9: 24-38. [CrossRef]

Jiang, Jing, Ang Gao, and Baiyin Yang. 2018. Employees' Critical Thinking, Leaders' Inspirational Motivation, and Voice Behavior: The Mediating Role of Voice Efficacy. Journal of Personnel Psychology 17: 33-41. [CrossRef]

Johnson, Ralph H., and Benjamin Hamby. 2015. A meta-level approach to the problem of defining "Critical Thinking". Argumentation 29: 417-430. [CrossRef]

Jones, Julie Scott. 2015. Research Ethics. Context and Practice. Thousand Oaks: SAGE Publishing.

Kincheloe, Joe L., and Shirley R. Steinberg. 1993. A Tentative Description of Post-Formal Thinking: The Critical Confrontation with Cognitive Theory. Harvard Educational Review 63: 296. [CrossRef]

King, Patricia M., and Karen Strohm Kitchener. 2004. Reflective Judgment: Theory and Research on the Development of Epistemic Assumptions through Adulthood. Educational Psychologist 39: 5-18. [CrossRef]

Kreitzberg, Anne Pauker, and Charlie B. Kreitzberg. 2011. The Business Case for Critical Thinking. Mworld 10: 23-26.

Krstikj, Aleksandra. 2021. Social Innovation in the Undergraduate Architecture Studio. Societies 11: 26. [CrossRef]

Kumar, R. Renjith, and Rajani James. 2015. Evaluation of Critical Thinking in Higher Education in Oman. International Journal of Higher Education 4: 33-43. [CrossRef]

Lauder, Hugh, and Ken Mayhew. 2020. Higher Education and the Labour Market: An Introduction. Oxford Review of Education 46: 1-9. [CrossRef]

Lipman, Matthew. 1988. Critical Thinking-What Can It Be? Educational Leadership 46: 38.

Magrabi, Syed Abdur Rauf, Moghal Irfan Pasha, and Moghal Yaseen Pasha. 2018. Classroom Teaching to Enhance Critical Thinking and Problem-Solving Skills for developing IOT Applications. Journal of Engineering Education Transformations 31: 152-57. [CrossRef]

Maloney, Stephen, Joanna Hong-Meng Tai, Kristin Lo, Elizabeth Molloy, and Dragan Ilic. 2013. Honesty in Critically Reflective Essays: An Analysis of Student Practice. Advances in Health Sciences Education 18: 617-26. [CrossRef]

Marton, Ference, Gloria Dall'Alba, and Elizabeth Beaty. 1993. Conceptions of learning. International Journal of Educational Research 19: 277-300.

Mathias, John. 2015. Thinking Like a Social Worker: Examining the Meaning of Critical Thinking in Social Work. Journal of Social Work Education 51: 457-74. [CrossRef]

McLaren, Peter. 2016. Pedagogy of Insurrection: From Resurrection to Revolution. New York: Peter Lang.

Niu, Lian, Linda S. Behar-Horenstein, and Cyndi W. Garvan. 2013. Do Instructional Interventions Influence College Students' Critical Thinking Skills? A Meta-Analysis. Educational Research Review 9: 114-28. [CrossRef]

Official Statistics Portal. n.d. Available online: https:/ / osp.stat.gov.lt/temines-lenteles7 (accessed on 16 June 2021).

Panter, Abigail T., and Sonya K. Sterba. 2011. Handbook of Ethics in Quantitative Methodology. New York: Routledge.

Paul, Richard, and Linda Elder. 2012. Critical Thinking: Tools for Taking Charge of your Learning and Your Life. Boston: Pearson.

Penkauskienè, Daiva, Asta Railienè, and Gonçalo Cruz. 2019. How Is Critical Thinking Valued by the Labour Market? Employer Perspectives from Different European Countries. Studies in Higher Education 44: 804-15. [CrossRef]

Phan, Huy P. 2011. Deep Processing Strategies and Critical Thinking: Developmental Trajectories Using Latent Growth Analyses. Journal of Educational Research 104: 283-94. [CrossRef]

Phillips, Denis Charles, and Nicholas C. Burbules. 2000. Postpositivism and Educational Research. Lanham: Rowman \& Littlefield.

Piawa, Chua Yan. 2010. Building a test to assess creative and critical thinking simultaneously. Procedia—Social and Behavioral Sciences 2: 551-59. [CrossRef]

Pithers, Robert T., and Rebecca Soden. 2000. Critical thinking in education: A review. Educational Research 42: 237-49. [CrossRef]

Pollard, Vikki. 2014. An Ontological Turn in Critical Thinking in Higher Education. In Research and Development in Higher Education: Higher Education in a Globalized World. Edited by Anna Kwan, Eva Wong, Theresa Kwong, Sam Lau and Allan Goody. Hong Kong: Herdsa, vol. 37, pp. 266-73.

Power, John B. 2016. Has This Begun to Change the Way They Think? Moving Undergraduate Learners' Level of Reflection from Where It Is to Where It Needs to Be. Teaching in Higher Education 21: 235-48. [CrossRef]

Powley, Edward H., and Scott N. Taylor. 2014. Pedagogical Approaches to Develop Critical Thinking and Crisis Leadership. Journal of Management Education 38: 560-85. [CrossRef] 
Puig, Blanca, Paloma Blanco-Anaya, Inés M. Bargiela, and Beatriz Crujeiras-Pérez. 2019. A Systematic Review on Critical Thinking Intervention Studies in Higher Education across Professional Fields. Studies in Higher Education 44: 860-69. [CrossRef]

Rave, Jorge Iván Pérez, Rafael Fernández Guerrero, and Juan Carlos Correa Morales. 2020. Critical thinking and continuous improvement: A scientific text mining approach. Total Quality Management. [CrossRef]

Redding, Gordon. 2017. Critical Thinking, University Autonomy, and Societal Evolution; Thoughts on a Research Agenda. Centre for Global Higher Education Working Paper No. 11. London: UCL Institute of Education.

Reed, Lynette. 2018. Building Critical Thinking Skills to Solve Problems at Work. Available online: https://www.business.com/ articles / building-critical-thinking-skills-at-work/ (accessed on 16 June 2021).

Resnick, Lauren B., and National Research Council. 1987. Education and Learning to Think. Washington, DC: National Academies Press.

Rodzalana, Shazaitul Azreen, and Maisarah Mohamed Saat. 2015. The Perception of Critical Thinking and Problem-Solving Skill among Malaysian Undergraduate Students. Procedia-Social and Behavioral Sciences 172: 725-32. [CrossRef]

Rogoff, Irit. 2006. “Smuggling”-An Embodied Criticality. Available online: https:/ /xenopraxis.net/readings/rogoff_smuggling.pdf (accessed on 16 June 2021).

Ruutmann, Tiia. 2019. Development of Critical Thinking and Reflection. In Linear and Nonlinear Programming January. Edited by Michael Auer and Thrasyvoulos Tsiatsos. Cham: Springer, pp. 895-906.

Saha, Ayesha, and Samridhi Ahuja. 2017. Critical Existential Thinking, Search for Meaning and Life Satisfaction. Journal of Psychosocial Research 12: 187-95.

Salkind, Neil J. 2010. Encyclopedia of Research Design. Thousand Oaks: SAGE Publications. [CrossRef]

Schraagen, Jan Maarten, and Josine G. M. van de Ven. 2008. Improving Decision Making in Crisis Response through Critical Thinking Support. Journal of Cognitive Engineering and Decision Making 2: 311-27. [CrossRef]

Sigurðsson, Geir. 2017. Transformative Critique: What Confucianism Can Contribute to Contemporary Education. Studies in Philosophy $\mathcal{E}$ Education 36: 131-46. [CrossRef]

Sousa, Maria José, and Daniela Wilks. 2018. Sustainable Skills for the World of Work in the Digital Age. Systems Research E Behavioral Science 35: 399-405. [CrossRef]

Stupnisky, Robert H., Robert D. Renaud, Lia M. Daniels, Tara L. Haynes, and Raymond P. Perry. 2008. The Interrelation of First-Year College Students' Critical Thinking Disposition, Perceived Academic Control, and Academic Achievement. Research in Higher Education 49: 513-30. [CrossRef]

Subramanian, Kalpathy Ramaiyer. 2020. Organizational aspirations and Critical Thinking of Managers. Journal of Advances in Social Science and Humanities 6: 1173-82. [CrossRef]

The State Social Insurance Fund Board SODRA. n.d. Available online: https:/ / www.sodra.lt/ (accessed on 16 June 2021).

Tripathy, Mitashree. 2020. Dimensions of Critical Thinking in Workplace Management \& Personal Development: A Conceptual Analysis. Multidisciplinary Journal for Education Social and Technological Sciences 7: 1-19. [CrossRef]

Ünsar, Agah Sinan, and Ediz Engin. 2013. A case study to determine critical thinking skills of university students. Procedia-Social and Behavioral Sciences 75: 563-69. [CrossRef]

Wang, Xiaoli, and Huibin Zheng. 2016. Reasoning Critical Thinking: Is It Born or Made? Theory E Practice in Language Studies 6: 1223-31. [CrossRef]

Whiting, Kate. 2020. These Are the Top 10 Job Skills of Tomorrow-And How Long It Takes to Learn Them. Available online: https: / / www.weforum.org/agenda/2020/10/top-10-work-skills-of-tomorrow-how-long-it-takes-to-learn-them/ (accessed on 16 June 2021).

Wolcott, Susan K. 2006. College Faculty Handbook: Steps for Better Thinking. A Classroom Model for Teaching, Learning and Assessing Higher Order Thinking Skills. Bellevue: Wolcott Lynch Associates.

World Economic Forum. 2020. The Future of Jobs Report 2020. Available online: http://www3.weforum.org/docs/WEF_Future_of_ Jobs_2020.pdf (accessed on 16 June 2021).

Yanchar, Stephen C., Brent D. Slife, and Russell Warne. 2008. Critical Thinking as Disciplinary Practice. Review of General Psychology 12: 265-281. [CrossRef]

Yuan, Yu-His, Chia-Hui Liu, and Szu-Sheng Kuang. 2021. An Innovative and Interactive Teaching Model for Cultivating Talent's Digital Literacy in Decision Making, Sustainability, and Computational Thinking. Sustainability 13: 5117. [CrossRef]

Zhang, Nan. 2020. On the Cultivation of Critical thinking ability in College English Class. International Journal of English, Literature and Social Sciences (IJELS) 5: 183-85. [CrossRef] 